\title{
再生可能エネルギーの普及に向けて \\ For the Spread of Renewable Energy
}

\section{本庄孝子* \\ Takako HONJO}

Key Words: Renewable Energy, Biomass, Wind, Solar, Geothermal

\section{1. 緒 言}

我が国のエネルギー構成はどのようにするのが一番いい のだろう。この度の原発事故を契機に、再生可能エネルギー が大きくクローズアップされた。再生可能エネルギーは太 陽光・熱、風力、水力、バイオマス、潮力、地熱、海流な どがあり、自然エネルギーとほぼ同じ意味で使われている。 再生可能エネルギーを使うことによって、化石燃料の消費 を減らし、 $\mathrm{CO}_{2}$ をほとんど排出しないことから温暖化対策 にも有効である。

世界においては、自然エネルギーに関する目標值や支援 政策を制定している国は 118 力国あり、このうち少なくと も半分は途上国である。2010 年の自然エネルギーに対する 投資は 2110 億ドル、前年に比べて $32 \%$ 増加している ${ }^{1)}$ 。 世界の石油生産量は 2030 年には半減すると言われ、2010 年のメキシコ湾原油流出事故は海底に延びる $5500 \mathrm{~m}$ のパ イプは、必要に迫られた結果であり、オイルピークはすで に迎えたと言われる。中東に目を転じれば、アラブ首長国 連邦は産油国から緑の大国へと宣言し、イランも原油枯渇 をにらみ、風力発電の倍増計画を進めている2)。

再生可能エネルギーの取り組みは世界の大きな流れに なっており、我が国においてもこの自国産の再生可能エネ ルギーの本格的な取り組みが進むことが切に望まれる。

再生可能エネルギーに積極的に取り組んでいるドイツや デンマークでは、 $\mathrm{CO}_{2}$ 削減と経済成長を同時に達成してい る。この2つの国に学ぶことは大きい。再生可能エネルギー 市場の 20 兆円は自動車産業と同じレベルである。再生可能 エネルギー市場はどんどん活発になっており、日本にもビ ジネスチャンスはあり、既に海外で活躍している企業もあ る。

我が国は火山国で、山が多く、海に囲まれていることか ら再生可能エネルギー資源は豊富にある。ここに我が国の 再生可能エネルギーの実態について述べ、次の時代への可 能性を探りたい。

\section{2. 再生可能エネルギー}

再生可能エネルギーは自然に由来するエネルギーの総称 といえ、太陽エネルギーに由来するのがほとんどである。 地熱のみが異なる。化石燃料の石炭、石油、天然ガスを除く。 再生可能エネルギーをここに列挙すると、太陽光、太陽熱、 風力、バイオマス、水力、地熱、潮汐、海流、波力、温度 差、雪水(冷) 熱、空気熱、地中熱、河川熱等といわれている。 再生可能エネルギーは地元のエネルギーで、活用によって 化石然料購入費を減らすことができ、太陽由来は発電して もそのおおもとが減らない、燃料の請求書もこない。再生 可能エネルギー産業から雇用が生まれるなどのメリットを 持つ。短所としては薄く分散しているので、集めて活用す るのに技術がいる。国土の地形や特徴に適する方式を探り、 改善をはかって普及したい。バイオマスエネルギーは活用 時に $\mathrm{CO}_{2}$ を排出するが、木の成長分の利用ならば、大気中 の $\mathrm{CO}_{2}$ は変化しないことから、カーボンニュートラルとさ れている。

我が国はほんの最近まで、新エネルギーが優先されてい た。新エネルギーは大型水力発電は除外されており、燃料 電池や、天然ガスコジェネレーション等が入り、補助金の 対象になったのが多かった。

実は IEA の再生可能エネルギーのデータは大型水力発電 を除外しており、別の項で記載されている。それ故、日本 の再生可能エネルギーは $3 \%$ と誤った情報が長く信じられ、 昨年までNHKもそう報道していた。ダムの水力発電が再 生可能エネルギーであるのは世界の常識であり、今やっと ダムの水力発電を加えた形で統計が示された。

新エネルギーの定義も時代と共に変化した。1995 年に地 熱が除外され、風力も以前、長い間補助の対象にならなかっ た。バイオマスエネルギーが新エネルギーに格付けされた のは 2002 年である。再生可能エネルギーについても現在、 政府が認めたものが補助の対象になっている。

2005 年を基準年にした世界と日本の再生可能エネルギー

*阪南大学（ T 580-8502 大阪府松原市天美東 5-4-33)

Hannan University (5-4-33 Amamihigashi, Matsubara, Osaka, 580-8502 Japan) 


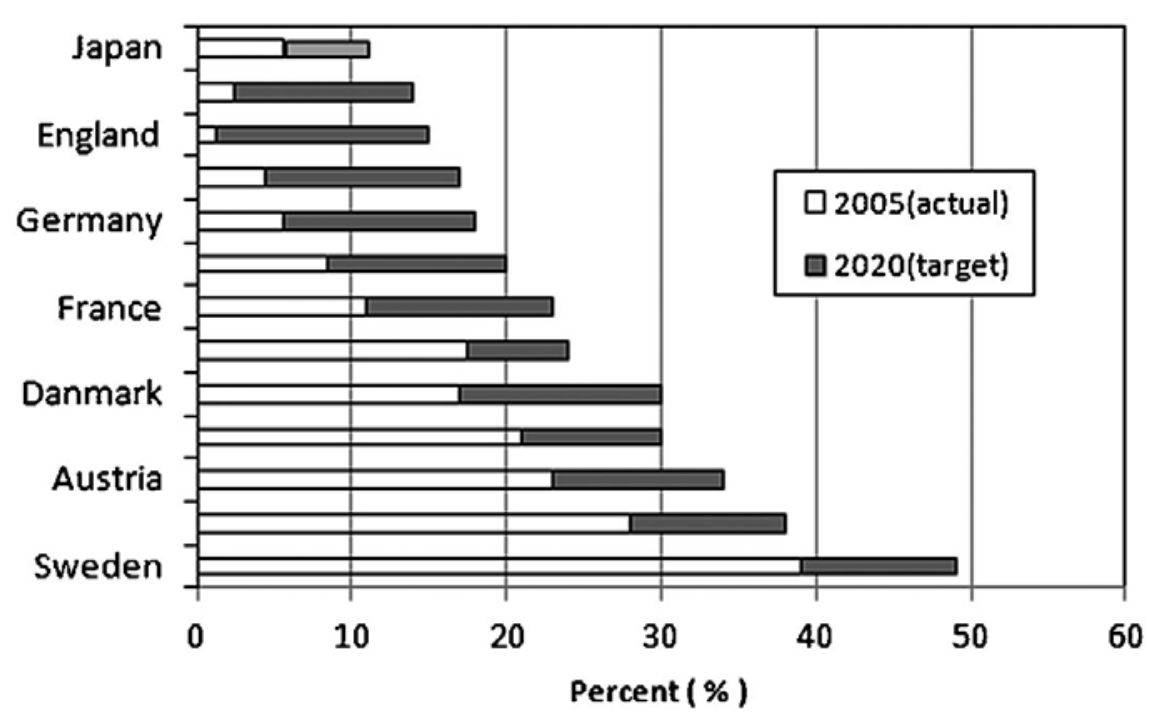

Fig. 1 The share of renewable energy in world

Table 1 Potential of renewable energy in Japan

\begin{tabular}{|l|c|}
\hline & $\begin{array}{c}\text { Amount can be introduced } \\
\left(10^{4} \mathrm{~kW}\right)\end{array}$ \\
\hline Solar power & 14,920 \\
\hline Wind power & 185,550 \\
\hline Small \& medium-sized hydropower & 1,440 \\
\hline Geothermal power & 1,420 \\
\hline
\end{tabular}

の割合を Fig. 1 に示す。2005 年では日本とドイツの再生 可能エネルギーの割合は同じである。日本の正式な目標值 は未定だが、2020 年の導入見込量は約 $11 \%$ とされており、 ここに変則的に付け加えた。

我が国の再生可能エネルギー資源量は多く、環境省の平 成 23 年 3 月「再生可能エネルギー導入ポテンシャル調査」 $\rfloor^{3}$ によると、太陽光、風力、中小水力、地熱の合計は九電力 発電量（約 2 万 $\mathrm{kW）の} 10$ 倍以上ある (Table 1)。このデー 夕にはバイオマスが抜けている。国土の 3 分の 2 が森林で ある我が国は、 1 年間の成長量の半分を利用すると仮定す れは、バイオマスは一次エネルギーの $20 \%$ を賄うことが できる ${ }^{4)}$

\section{1 日本の再生可能エネルギーの歴史}

我が国の 1 次エネルギーの供給推移を Fig. $2^{5)}$ に示す。 1960 年頃までは水力の割合が大きいことがわかる。また 1960 年以前の民生エネルギーは、薪炭に代表されるバイオ マスエネルギーがたくさん使用されていたが、Fig. 2 には 薪炭のデータは含まれていない。

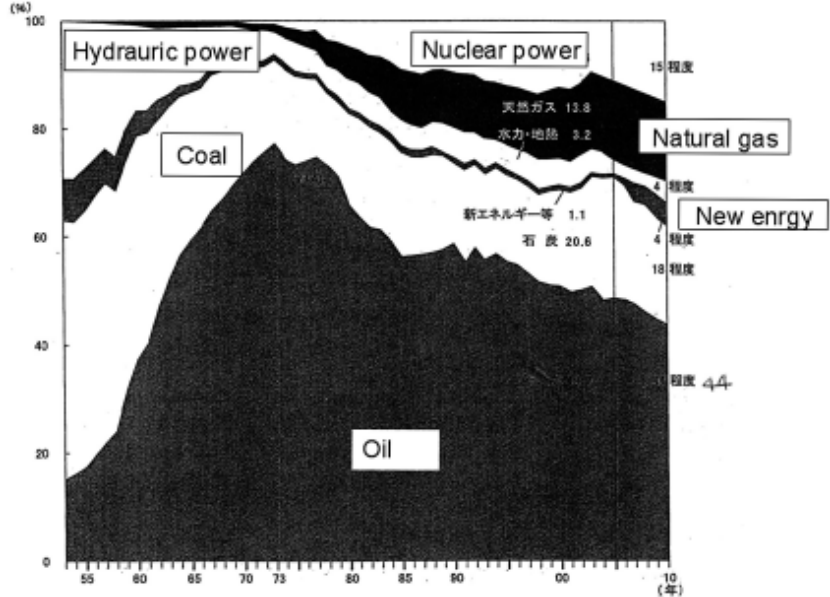

Fig. 2 Trends in Japan's primary energy supply ${ }^{5}$

2010 年の 1 次エネルギー供給量は資源エネ庁からのデー 夕 ${ }^{6)}$ から Fig. 3 に示すように、石油 $38.3 \%$ 、石炭 $21.5 \%$ 、 天然ガス $18.3 \%$ 、原子力 $10.8 \%$ 、水力 $3.1 \%$ 、再生可能工 ネルギー $3.5 \%$ とある。ところが真の意味の再生可能エネ ルギーは水力を加えた $6.6 \%$ であることがわかる。

水力

Fig. 2 から判るように、1955 年頃の我が国の電力は主に 石炭火力発電とダムの水力発電によって支えられていた。

小水力発電は、昭和 20 年代に全国山村各地で村単位や集 落単位で、小規模な電灯用自家発電所が建設されていたが、 電力会社の送電設備が整い順次廃止された。昭和 25 年に補 助金 1 億円で、全国で 16 か所の小水力発電の建設が始まり、 昭和 27 年「農山漁村電気導入促進法」が議員立法で制定さ 


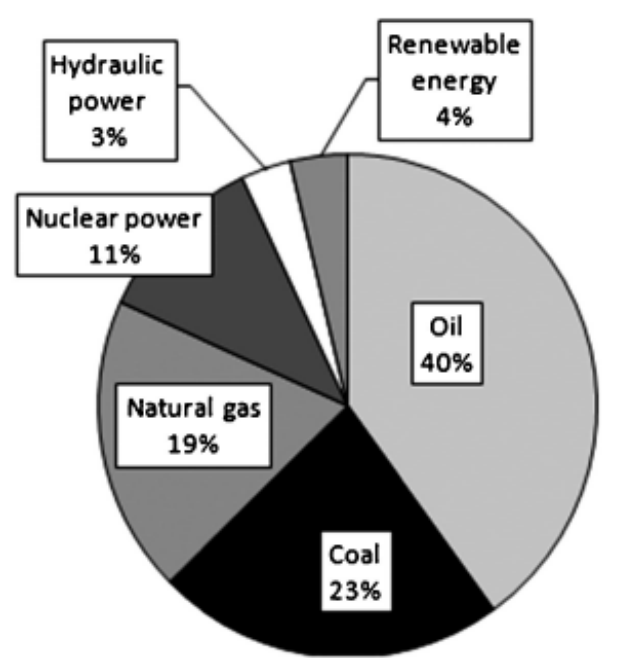

Fig. 3 Primary energy of Japan (2010)

れ、各地で導入が進んだ7。この陰に織田史郎の理念と努 力があった。中国地方に扔いては昭和 45 年までに約 90 か 所の小水力発電所を建設した。中国電力では、配電線を連 係した全量売電方式が認められた。

昭和 30 年中期から大型石油火力発電の建設で発電原価が 下がり、小水力発電の原価が対応しきれなくなった。設備 も老朽化し、川での発電の権利は電力会社に購入されたと ころもあった。

昭和 48 年の石油ショックで水力発電が見直され通産省補 助金（15～ $30 \% ）$ が認められた。電気卸事業者の公営企 業（県、市営発電所）が補助金で新規に建設を進めた。自 家用小水力は法的に余剩売電のため売電価格が低く、農水 省の補助金（50～70\%）の適用を受ける土地改良区が建 設を行うことができた。小水力発電は落差が $1 \mathrm{~m}$ あればよ く、農業用水や浄水場、小さな河川などで活用される。身 近なところでは嵐山の渡月橋の照明、豊中市の浄水配水場 で見られる。だが、法規制などがあり普及にはかなりの努 力を必要としている。長野県の小水力は特区として認めら れて実現した経緯がある ${ }^{8)}$ 。

\section{バイオマス・メタン発酵}

メタン発酵は我が国では 1924 年に京大と大阪市衛生試験 所で実験研究が始まった。そして、昭和の初期に東京、大阪、 京都、名古屋など大都市に下水城処理施設が建設された際 に嫌気性消化施設が建設された。大阪市は 1925 年市岡下水 処理実験施設が稼働した ${ }^{9)}$ 。当時、民間では高野山で下水 処理施設第 1 号と言われ ${ }^{10)} 、 1932$ 年名古屋市で污泥を消化 槽と天日乾燥床により処理した。我が国ではメタン発酵と 言わずに「消化」と呼び、現在でも下水道関係ではそう呼 ばれている。1942 年に、京都・鳥羽処理場でメタンガスを 分離、150気圧にしてボンべに詰めた。

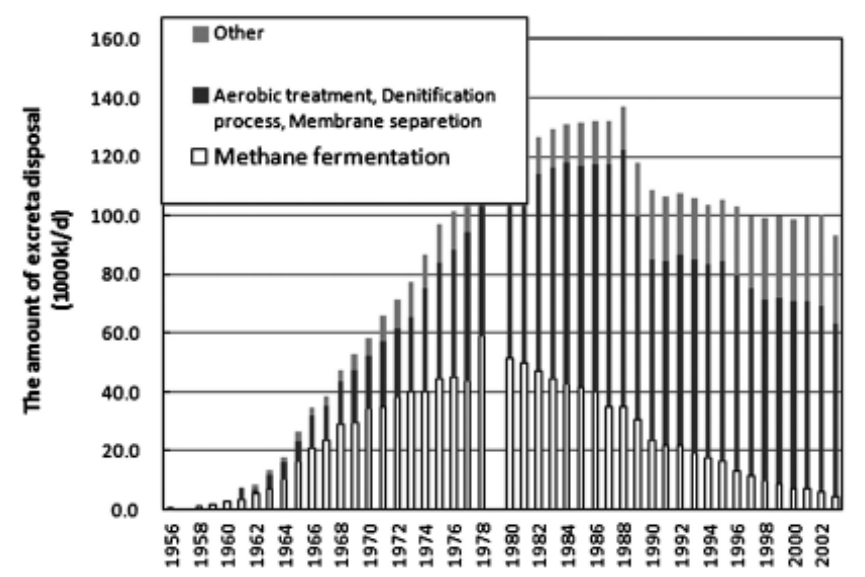

Fig. 4 Change per year of amount of excreta disposal in Japan ${ }^{10)}$

1944 年廣瀬孝六郎がし尿の嫌気性消化の研究に関する論 文を 1946 年にかけて 4 報発表し、戦後のし尿処理法の基本 となる ${ }^{9)}$ 。

敗戦後の産業が活発になり始めた頃の 1950 年代にエネル ギー不足によるメタン発酵のブームがあった。1953 年にメ タン発酵に国庫による補助金制度が出来た。1962 年には家 畜粪尿で 180 基のメタン発酵施設が稼働していた ${ }^{11)}$ 。そし てし尿処理施設はほとんどメタン発酵の嫌気性消化方式を 採用していた。その主な目的はエネルギーを得るのではな く、下水污泥の減容化として盛んに取り入れられた。1970 年頃には、全下水道施設の $90 \%$ 以上に嫌気性消化施設が あった (Fig. 4) ${ }^{10)}$ 。また農家の生活改良普及事業の一環とし て家畜粪尿等からバイオガスを生産し、農家はメ夕ン発酵 槽を設置して、炊事等の生活然料にバイオガスを利用し、 消化液は肥料として利用していた。しかしこのブームは長 く続かなかった。プロパンガスの普及および農家の作業効 率や利便性の追求により、メタン発酵は自然に採用されな くなった。

1964 年に第 2 回国際水質污濁会議（現在の IWA）が日本 で開催され、参加者は日本のし尿処理場を見学して驚嘆し た ${ }^{12)}$ 。それはし尿処理技術が日本で独自に開発が進んでい たことで、し尿にメタン発酵を用いたことは世界に誇る高 度な技術であった。一方、我が国では、世界で注目された にもかかわらず、一部の研究者を除いてその認識が無く、 下水道でメタン発酵も衰退していった。近年、下水道処理 施設は、水質規制の強化により酸化方式や標準脱腔方式の 採用で、嫌気性消化施設は次第に建設されなくなった。野 池 ${ }^{12)}$ は、当時の日本は、本来最大の利点であるエネルギー 回収をはじめとするメタン発酵の重要性が正しく強調され なかったと述べている。事実、私が 2007 年に大阪市の下水 処理施設を見学したおり、発酵メタンガスで $400 \mathrm{~kW}$ 発電 していたので「すばらしい、バイオマスエネルギーの活用 


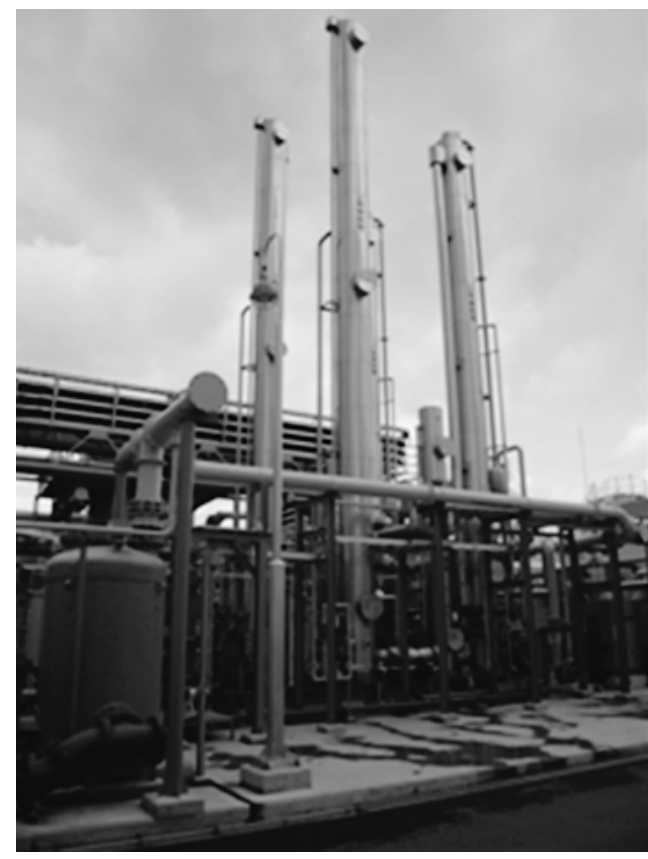

Photo 1 Methane separation device of a sewage treatment plant in Kobe

をしている、パンフレットにこのことを書いて PR したら よい」と助言したが、担当者は全くその認識がなくきょと んとしていた。

家畜粪尿のメタン発酵は北海道の酪農家等に重宝されて いた。ところが、酪農政策の弱体で離農者が増えている部 分がある。八木町、小岩井農場などは健在である。

現在では大手食品会社などでメタン発酵が取り組まれ、 得られたメタンガスを燃料電池等に利用することが研究さ れている。神戸市の下水処理場では、得られたメタンガス でバスを走らせると共に、メタンガスを調整して大阪ガス のパイプに混入している (Photo 1)。

\subsection{0 年代のオイルショック以後}

1973 年の第 1 次オイルショックの時、我が国は 8 割近 くのエネルギーを石油に頼っていた。翌年「新エネルギー 技術開発制度」（サンシャイン計画）を発足させ、太陽を メインとする自然エネルギーと、水素エネルギーを新エネ ルギーとして石油代替えエネルギーとして開発普及を進め た。実はこの原案はオイルショックの前に、通産省工業技 術院の工業技術会議で提案されていた ${ }^{13)}$ 。1974 年、工業技 術会議を解散して産業技術審議会から「新エネルギー技術 開発のすすめ方について」の答申が出された。これを契機 に太陽光、太陽熱、風力、地熱、波力、潮汐、木質など再 生可能エネルギーの研究開発が進み、実証が各地で取り組 まれた。予算は石炭特会・石油特会（特別会計）である。

1978 年の第 2 次オイルショック後には、省エネルギー の「ムーンライト計画」が始まり、産官学で新エネルギー、
省エネルギーの技術開発に努め、産業界がエネルギーの効 率的利用を積極的に進めた結果、製造業のエネルギー効率 は 1975 年に比べ、1990 年には大幅に改善して、エネルギー 消費を 40 〜 50 \% 削減する世界の最高水準に達した ${ }^{14)}$ 。こ の年我が国は『地球再生計画』を国連で発表した。「産業 革命以降の 200 年に様々な負荷をかけて変化させてきた地 球を、今後 100 年かけて再生しよう」と、世界的な省エネ ルギーの推進、クリーンエネルギーの導入、環境技術開発、 $\mathrm{CO}_{2}$ 吸収源の拡大、革新的エネルギー関連技術の開発を訴 えた。これはRITE（地球環境産業技術機構）が主になって 提案した。その後、石油価格の安価な時を経て、1993 年に、 サンシャイン計画とムーンライト計画、地球環境技術開発 制度を統合して「ニューサンシャイン計画」が発足した。 この時、太陽光発電と水素エネルギーに重点化し、風力発 電や地熱発電などが切り捨てられた。そして 1990 年以降は、 我が国の製造業のエネルギー効率は停滞ないし増加の傾向 にある。

EUではチェルノブイリ事故後に、再生可能エネルギー の取り組みが進んだ。北欧やドイツ、デンマークでは大き く普及している。EUの特徵は、EU 全体に太い電力網があ るとともに、ロシアからの天然ガスの供給と、フランスの 原子力発電の供給がある。電力の輸出入は臨機応変に行わ れている。

我国は 2003 年に、新エネルギーの一定割合の電力を電力 会社が購入義務の「RPS 制度」を導入した。その義務量が 1.4 $\%$ 程でとても小さく、北海道や東北地方では風力発電の申 請が多いが、抑制される方向に働いている。ちなみに英国 の RPS 義務量は $10 \%$ である。

再生可能エネルギーの導入が進んでいる国は「固定価格 買取制度」（FIT：Feed-in tariff）が多い。我が国は2012 年 7 月 1 日から全量固定価格買取制が導入され、これから普 及が期待される。規模によって買い取り価格と期間が設定 され ${ }^{15)} 、 3$ 年間は儲けるように配慮されている。太陽光発 電の買い取り価格は 2013 年度に下がるという。

普及が進んでいる諸外国では法整備が進んでおり、ドイ ツのバイオマス法は省庁を越えて活用が進むシステムが確 立している。スエーデンでは環境関連する 15 の法律を 1 つ にまとめて、環境法典（33 章）とした ${ }^{16)}$ 。

\section{3. 我が国の特徵}

北欧の国々はオイルショック後のエネルギー政策を国民 と共に取り組んできたが、我が国において政府は産業界だ けを対象にした。我が国のエネルギー政策は政府と大手電 力会社、大手ガス会社の意向に沿って作ったといってよい。 そして新エネルギーの普及を前面に出し、自然エネルギー の普及という観点はからだんだん離れていった。政府は 2002 年に、2010 年における新エネルギーの目標を $3 \%$ と した。2010 年に新エネルギー $3 \%$ を達成したが、政権が変 
わっていたので、政府からの報告は何もなかった。

政府は 2004 年に「2030 年のエネルギー需給展望」を 出した。次の政権が 2010 年に出した「エネルギー基本計 画」の中身は、ほとんどこの「2030 年のエネルギー需給展 望」を踏襲しており、 $\mathrm{CO}_{2}$ ゼロエミッションの電源として、 2030 年までに少なくとも原子力発電を 14 基増設するとし たのが特徴であった。今回の原発事故が起こるまで、国民 のほとんどが、その実態を知らず、再生可能エネルギーの 概念がほん最近まで希薄であった。

実は 2004 年、中学校の教科書検定で、「原子力の長所部 分が足りない」「自然エネルギーは長所を強調しすぎてい る」と指摘され、教科書会社は意向に沿った内容の改訂を し、翌年には高校の教科書が同様に指摘され、意向に沿っ た改訂が行われた ${ }^{17)}$ 。残念なことにこの事実は報道されな かった。国民に事実を知らせることをゆがめてしまった経 緯がある。この年は 1 年で政権が 2 回変わった時でもある。 2011 年福島原発事故以後、エネルギー基本計画を白紙に 戻すと宣言したが、まだそのままである。我が国の再生可 能エネルギーの割合 $6.6 \%$ をふまえて、国民も参加した形 の新たなエネルギー基本計画を作る時に来ている。

2012 年 9 月 19 日の閣議では「新たなエネルギー政策」 が決定されなかったが、5 日前のエネルギー・環境会議で 決定した「2030 年代に原発稼働ゼロを可能にするよう、あ らゆる政策資源を投入する」を盛り込んた「革新的エネル ギー・環境戦略」は参考文書とし、「原発 40 年で廃炉」「原 発の新増設は原則として行わない」等になった。原発の稼 働についてこの 2012 年 8 月に行われた討論型世論調查は世 界最初の試みであった。1 ケ月の討論の結果、原発 $0 \%$ の 人の割合が $32.6 \%$ から討論後 $46.7 \%$ に増えた。これらを 踏まえ新たなエネルギー基本計画の作製が待たれる。

ドイツで再生可能エネルギーへの市民の投資が大きいの は、福祉・医療制度など充実しており将来に対して不安が なく、共稼ぎで稼いだお金を、そのまま再生可能エネルギー に投資している。銀行へ預ける利子よりも良いそうだ。デ ンマークでもそのような傾向と聞く。また、環境に配慮し た会社へ投資した場合、他の会社に比べ、配当金の税金を 安くする措置がとられている。住民が参加しやすいきめ細 やかな制度の充実も求められる。

\section{太陽光発電}

太陽光発電は政府も企業も力を入れて、日本は 2004 年 まで世界一発電していた。かつて太陽光発電のセルの製造 も日本企業の独擅場であった。2005 年、当時 EUでは再生 可能エネルギーの取り組みが加速していた時期に、なぜか 太陽光発電の補助制度が打ち切られ、その後日本の地位は 下落していった。太陽光発電セル製造の企業は輸出に活路 を見出し、EUの大型施設等に活用された。2009年にわず かに補助金が復活し、同年 11 月に余㮃電力を通常購入価格 の 2 倍の 48 円 / kWh で売電できる制度が発足し、やっと

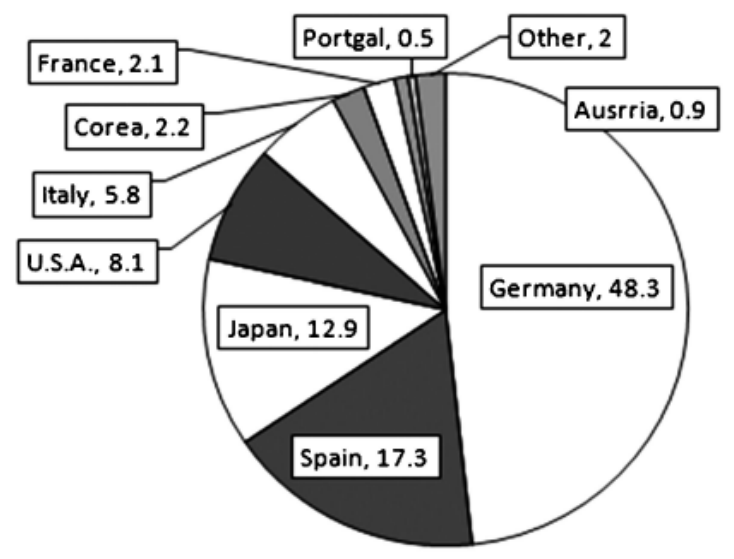

Fig. 5 Solar power generation capacity of IEA countries (2009)

上昇に向いた。最近はスペインにも抜かれ 3 位である (Fig. 5) ${ }^{18)}$ 。現在、太陽電池は中国が世界の $40 \%$ 生産し、海外に 輸出している。余波を受けてか、長年世界一の生産を誇っ たドイツの Q セルズ社や、アメリカの企業も多数倒産した。

太陽光発電の発電効率は主流は $15 \%$ である。2012 年 7 月の FIT 制度の導入で各地にメガソーラが計画されている。 現在稼働中、建設・計画中のメガソーラーは全国に 80 ケ所 ある。内 48 ケ所が電力会社以外である。東京電力の浮島太 陽光発電所は 7 メガを発電し、敷地は 11 ha である。太陽 光発電は敷地の確保の課題がある。メガソーラーは大手企 業が主体であるが、淡路島など自治体が積極的に取り組ん でいるところもある。長野県飯田市の「おひさま進歩エネ ルギー株式会社」、自然エネルギー市民の会の「ぽつぽおひ さま発電」など市民発電にも注目したい。市民ファンドが 各地で展開されている。

世界では他に集光型太陽光発電の関心も高まっている。

\section{太陽熱}

かつて我が国の再生可能エネルギーは水力、パルプ工場 の廃液であるバイオマスの「黒液」、太陽熱温水器、地熱が メインであった。太陽熱温水器はかなり前から補助がなく なり、普及は止まったままである。太陽熱温水器の効率は 太陽光発電よりも良くもっと普及させることが望まれる。 地方自治体で補助を出しているところもある。世界にあっ ては中国の取り組みが大きく、世界の $75 \%$ を占める ${ }^{18)}$ 。

\section{風力発電}

世界の風力発電導入量を Fig. 6 $6^{14)}$ に示す。2009 年までは 米国が世界一であったが、2010 年には中国が世界一になっ た。中国の風力は 3 割が送電網に繋がれていない。この図 から中国、米国、ドイツ、スペイン、インドの伸びが著し いことがわかる。世界では加速度的に普及が広がっている。 $\mathrm{EU}$ などでは洋上風力の広がりがある。風車の製造はデン マーク、中国、ドイツ、スペイン、インド、米国が主である。 


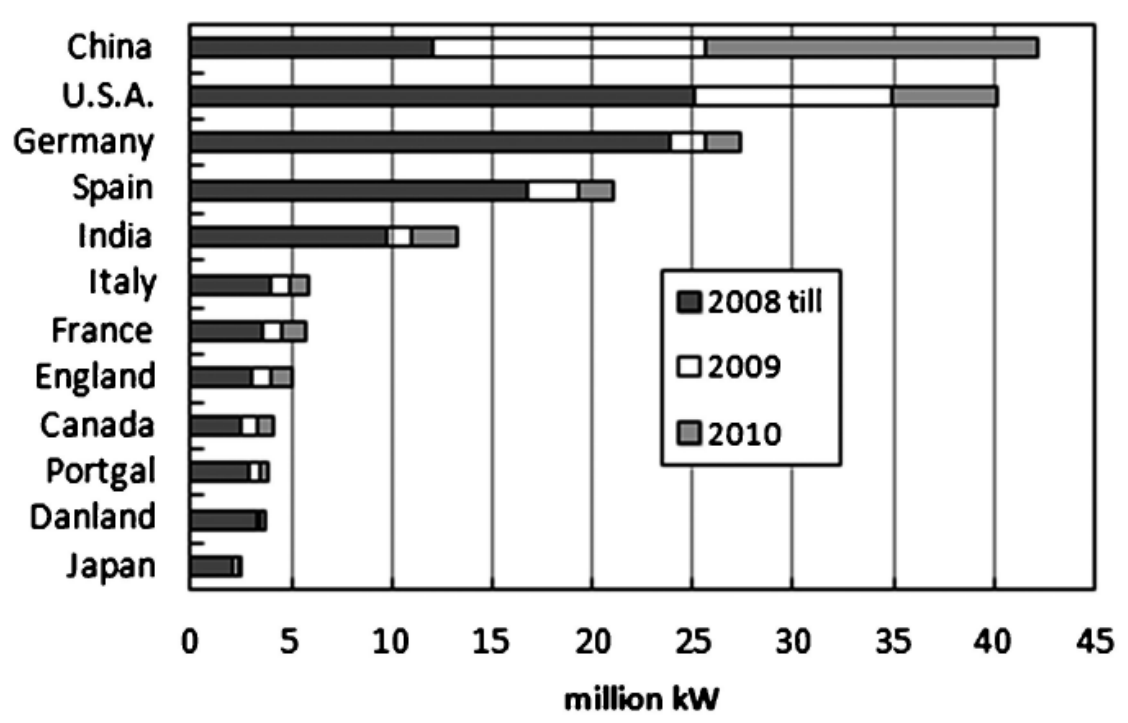

Fig. 6 Introduction amount of wind power (2010)

我が国は山が多くて風況は悪く $\mathrm{J}$ クラスである。それ故、 我が国の風況に合った風車の開発が必要であったが、政府 はなぜか 15 年ほど前に、研究開発の必要はないとした。日 本の風力資源は北海道、東北、九州に多いが、近年、電力 会社は RPS 制度を盾に、100 件以上風車建設の申請があっ ても 10 件ぐらいしか認めなかった。それでも各地にウイン ドファームが建設されて発電量は少しずつ増加している。

この度の東北大震災では、風力発電は全部無事で、東北 電力からフルに動かして下さいと要請があった。地元産の 再生可能エネルギーの価值が見直された。

日本の電力網は、大型発電所と電力を大量消費する工場 間に、太い電力網があり、その他は細い電力網からなって いる。それ故、変動の大きい電力が系統にはいると電気の 安定が損なわれるという。日本も EUみたいに太い電力網 のネットワークが出来れば、変動する電力も多量に受け入 れることができるのではないか。

実は、日本は風力発電機を輸出しており、米国に 1000 機 輸出している。最近では現在の風車よりはるかに大きい風 車の注文が海外からあり、日本企業が受注したという。日 本の技術の高さを海外が認めている。秋田では沿岸等に風 力発電を、日本製風車 1000 本の計画を進めている。一方、 デンマークの洋上発電に日本の商社が投資している。

風力発電に対する課題がいくつかある。バードストライ クの害は都市のガラス張りビルディングの方が風車より大 きい。だが渡り鳥のコースを外すなどの配慮がいるであろ う。低周波の問題は、今後、洋上発電により解決していく のではなかろうか。FIT 制度の導入でも風力発電の伸びは $1 \%$ と低く、この 12 月 16 日に規制緩和として、環境調査 の影響を国が行うことになった。

デンマークでは畑の $25 \mathrm{~m}^{2}$ は自由に使っても良いという

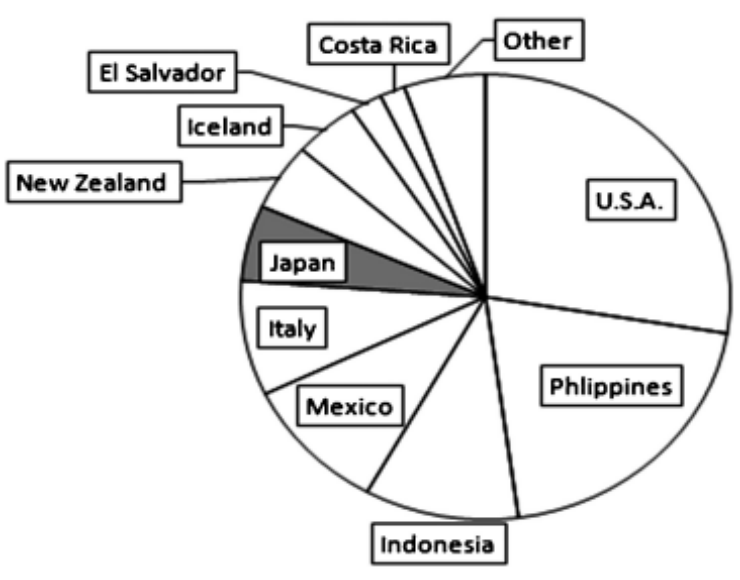

Fig. 7 Geothermal power (2008)

法律があり、畑に風車が樹立している。

$\mathrm{EU}$ は $50 \mathrm{~m}$ 以下の浅い海が広がり、着床式洋上発電が設 置できる。一方、我が国はすぐ深い海になり、浮体式洋上 発電が検討されており、技術開発が進んでいる。

現在、再生可能エネルギーで自給自足している自治体は 全国で 52 市町村あり、風力発電を取り入れているところが 多い。

\section{地熱発電}

地熱は再生可能エネルギーのなかで唯一太陽由来でな い。地熱資源量は活火山数と正の関係にあり、インドネシ ア、アメリカ、日本が 3 大資源国である。世界の地熱発電 を Fig. $7^{18)}$ に示す。我が国の地熱の理論的埋蔵量である「賦 存量」は設備量にして約 3300 万 $\mathrm{kW}$ だが、この值は地形や 法規制等の制約条件を考慮してある。我が国の発電量は資 
源量に比べて小さく世界 5 位である。実は世界の地熱発電 設備容量の約 $70 \%$ は日本製である。我が国は資源と技術 をフルに活用できる利点を持つ。

2012 年、国立公園内に公園外から斜めから掘ることが可 能になったが、パイプの長さが長くなる分、費用がかかる。 今後、特区として公園内での建設を認める方向がいるので はないか。現在は污染の害などを最小限度にする技術があ る。

\section{バイオマス}

バイオマスはマテリアル利用とエネルギー利用がある。 はじめにマテリアル利用してカスケード利用して最後にエ ネルギー活用を考える。バイオマスは発電よりも先ず熱利 用が主にする方がよい。EUでは $67.3 \%$ が熱利用に使われ、 発電は約 $25 \%$ 、残りが輸送用である。発電と熱利用の両方 のコジェネレーションにすると利用効率は良くなる。今後、 FIT 制度では電力だけでなく、熱の利用も対象にすること が望まれる。

2006 年、EUにおけるバイオマス原料は $79.6 \%$ が木質、 バイオガス $6.8 \%$ 、再生可能な都市固形廃棄物 $6.8 \%$ 、バイ 才燃料 $6.9 \%$ である ${ }^{19)}$ 。我が国も自国産木材の活用を増や し、そこからでる廃棄物を有効利用することが望まれる。 先進国中、製材所が元気でないのは日本だけである ${ }^{20)}$ 。日 本のスギ材は世界一の安い木材になった。

中山間地域や農業での熱利用を徐々にバイオマスエネル ギーに変えていくのは無理のない方向だと思う。農業用八 ウスの熱源をバイオマスに変える動きが始まっている。薪 ストーブの活用も広がりつつある。廃パレットを活用した 地域循環システムもある ${ }^{21)}$ 。

我が国の木材の自給率は、現在 $25 \%$ であり、食糧自給 率より低い。今後、自らの森をそのままにして、海外の資 源に頼るのはいかがなものであろうか。1965 年には木材の 自給率 $71 \%$ であった ${ }^{22)}$ 。山林は放置すると、崩壊が始まる。 近年の深層崩壊は植林した山に起こっていることが多い。 山の木材の活用によって国土の保全を保つことができる。

山国であるオーストリアは林業が盛んで、バイオマス利 用も大きい。学ぶところが多いのではなかろうか。そのた めには国の政策が重要である。

日本は国土の $67 \%$ が山で森林大国である。山の蓄積率 は世界一だが、放置林が多く、資源が無䭾になっている。 2008 年の自然エネルギーの活用 ${ }^{23)}$ は Fig. 8 に見られるよ うに、バイオマスは風力の 4 倍、太陽光の 6 倍である。バ イオマスをもっと積極的に活用を図れば、さらなる可能性 を秘めていることがわかる。最近、火力発電では石炭バイ オマス混焼もすすんでいる。

新しい燃料として、バイオマスを石炭コークスの代替え に活用するバイオコークスがある。井田らの提案 ${ }^{24)}$ で、お 茶がらや木くず等を原料にして約 $200{ }^{\circ} \mathrm{C} 、 30 \mathrm{MPa}$ で成型さ れる。成形体の成分はほとんど原料と同じだが、比重が 1.3

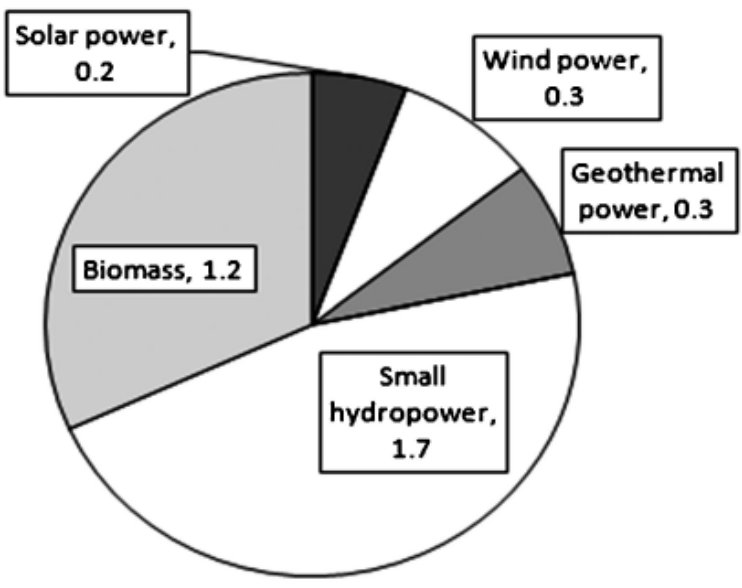

Fig. 8 Renewable energy in Japan in 2008 (Except solar heat \& large hydro)

付近と大きく、強度も大きい。高槻では間伐材等から径 10 $\mathrm{cm}$ 、長さ $20 \mathrm{~cm}$ 大のバイオコークスが 24 時間運転されて おり、製品は豊田自動織機に送られ、実用大型鋳造炉でコー クスの $10 \%$ を代替えしている ${ }^{25)}$ 。

最近 EUなどでトレファイドペレットが注目されてい る。トレファイドは半炭化のことである。通常のペレット に対してエネルギー密度が高く、保存性がいいのが特徴だ。 半炭化ペレットに関して日本が最初に国際会議で発表し た ${ }^{26)}$ 。

バイオマスをガス化して発電や、燃料を作ることが多数 取り組まれて抢り、将来性が大きい。

北欧を始め米国等では木質バイオマス発電が盛んだ。我 が国でもバイオマスで 1 万 $\mathrm{kW}$ 発電がいくつか取り組まれ ている。デンマークではワラを燃料にした大型発電が盛ん だ。この度日本の商社が英国のワラ燃料のバイオマス発電 を受注した ${ }^{27)}$ 。

我が国のバイオマス活用のためには日本の材の活用を進 めることが必要だ。新築の半分は戸建て住宅と言われ、そ こにもっと活用する必要がある。世界ではバイオマスの活 用は木質が主である。チップ、ペレット、ブリケット、炭、 オガライト、オガ炭、バイオコークス、トレファイドペレッ トなど活用していきたい。オガライト、オガ炭は日本の発 明である ${ }^{28)}$ 。

真庭市の銘建工業(株は輸入材などから集成材を製造する メーカーであり、古くからバイオマスエネルギーに取り組 んでいる。プレーナークズ（かんなクズ）でバイオマス発 電し、売電とグリーン証書を活用している。プレーナーク ズからペレットの製造は簡単で粉砝行程が必要でない。銘 建のペレットの製造量は日本一である。世界ではオガクズ やプレーナークズからペレットを作っている。

バイオ燃料は自動車や船などの燃料に用いられ、バイオ 
エタノール、バイオデイーゼルオイル、バイオメタンがあ る。バイオ燃料は食料と競合の問題及び遺伝子組み換え作 物の問題がある。バイオエタノールはエネルギー効率の点 で問題が多い。また 40 リットルのバイオエタノールは大人 半年分の食料に匹敵する。現在、食料と競合しない第 2 世 代の原料が研究されている。

バイオエタノールはトウモロコシ、サトウキビ、キャッ サバ、規格外小麦・米、廃糖蜜などから作られ、バイオディー ゼルオイルは大豆油、ナタネ油、ヒマワリ油、アブラヤシ （パームヤシ）油などから、バイオガスは下水污泥、家畜粪 尿、食品廃棄物等から作られる。ブラジルのサトウキビか らのバイオエタノールは、バガスを燃料にして蒸留される ことからエネルギー効率がよい。EUのナタネからのバイ オディーゼル然料 (BDF) はかつて休耕田だったところに菜 の花を植えて活用していることから一定の評価はある。我 が国の廃天ぷら油からバイオデイーゼル燃料の製造は、廃 棄物の活用という点で意義がある。菜の花とリンクさせた 「菜の花のプロジェクト」 ${ }^{29)}$ は日本の特色で、現在約 160 ケ 所で取り組まれている。京都市では市バスの 93 台が $\mathrm{B} 20$ (バ イオデイゼルオイル 20、軽油 80）で、ゴミ回収車約 140 台が B100 で走っている。廃食油を BDF 化するにはエネル ギーと費用がかかる。廃食油を簡単な濾過や遠心分離で精 製してそのまま活用する SVO (Straight Vegetable Oil) 法があ る ${ }^{30)}$ 。ドイツでは普及しているが、我が国ではマニア等が 愛好しているにすぎない。日本でもSVO 利用が普及するよ うな制度が求められる。

我が国ではガソリンにバイオエタノール 3 \% 混合の E3 と、軽油にバイオディーゼルオイルを 5 \% 混入する B5 が 認められている。E3 はバイオエタノールの分は税が免除さ れるが、B5 の場合は全量に税金が掛けられる不公平さがあ る。京都市の B100は税の対象外だが、B20 は全量に税が かかる。

我が国は平成 21 年に「バイオマス活用推進基本法」が制 定されたが、根本のところで統一的な扱いがされていない。 下水污泥のメ夕ン発酵は国土交通省、家畜粪尿のメ夕ン発 酵は農林水産省、食品工業残椬のメタン発酵は経済産業省 の管轄になっている。補助金申請は現在これら各省と環境 省が当たっている。

\section{潮汐発電 (潮力発電)}

干満の差を利用した潮汐発電は、1966 年にフランスのラ ンス潮汐発電所が完成して、翌年から最大定格出力 24 万 $\mathrm{kW}$ で発電し、世界最大規模である。2011 年、韓国のソウ ルから南西 $40 \mathrm{~km}$ の始華湖（シファホ）潮力発電所の 6 基 が発電を開始し、あと 4 基は試運転をすることになってお り、将来はランス発電を上回るという。我が国は青森県大 間崎における潮力発電の構想がある。

\section{海流発電}

海に囲まれた我が国は黒潮の流れが陸地の近くを通り、
海流発電が出来れば将来のエネルギーにとって朗報とな る。現在はエンジニアリング振興協会により MWh 級の海 流発電システムの実用化に向けて検討が行われているほ か、企業、大学等が連携して研究開発が進められている。 我が国は 1983 ～ 1988 年に来島海峡において潮流発電した。

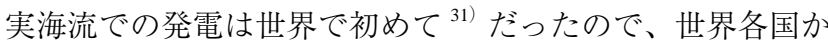
らプロジェクト視察があった。その後、海流発電は新エネ ルギーの対象からはずれ、暗黒の時代をむかえその間、鈴 木清美が海流発電の重要性を訴え続けていた。海流発電は 風力発電に比べ、媒体の密度が大きい点が異なるが、風力 発電を応用することができる。ループ型発電、プロペラ型 発電、マグロ型発電などがある。

\section{ゴミ発電}

EUでは都市ゴミの発電はバイオマスエネルギーになっ ている。我が国ではこの度の FIT 制度では廃衰物発電は 17.85 円／kWh となった。メタン発酵ガス化の 40.95 円／ kWh に比べ低価格である。

大都市のゴミ発電は大いに貢献している。大阪市ではゴ ミ発電で 5 億円／年稼いでいる。ただし、大型家具などを 粉砕する粉砕機の消耗品にかなりの費用がかかるようだ。

最近 EU では都市ゴミを埋め立てることをやめて、焼却 してゴミ発電に取り組んでいる。英国は日本のゴミ発電の 技術を導入した。デンマークでは、ゴミの量が不足して英 国から輸入している。

\section{4. まとめ}

世界の再生可能エネの取り組みは活発である ${ }^{1,32)}$ 。我が 国は再生可能エネルギーの技術も資源もあり、現状はこれ までの政策によるところが大きい。今後、これらの利点を フルに活用して、世界の範たる再生可能エネルギー国にな るチャンスである。

再生可能エネルギーはエネルギーの塊である化石燃料に 比べてハンディが大きい。そのハンディに応じて炭素税な どがある。我が国は地球温暖化対策税（炭素税）を 2012 年 10 月に導入した。

日本の商社が海外の再生可能エネルギーのプロジェクト にいくつか参入している。デンマークの酪農家共同体が運 営する家畜粪尿のレンヴィーバイオガス (Lemvig Biogas) ${ }^{33)}$ は日本の資本が入っている。我国においても FIT 制度が始 まる 7 月を契機に海外資本が入ってくるであろう。この時、 デンマークのように地域住民が $20 \%$ 参画出来るような法 整備が必要であると考える。

今、再生可能エネルギーを使った仕組みが種々考えられ ている。2010 年 4 月から新丸ビルで使う電力を青森県の風 力発電で賄っている。「生グリーン電力」と呼び、買う契約 を結んでいる ${ }^{34)}$

再生可能エネルギーは地域に産するエネルギーであり、 地域の自立、地域のエネルギーの創出を考える時に来てい 
る。

我国には国の統計が国民に知らされているとは言い難 い。部分的なデー夕はあるが、全部を網羅したトータルの データがない。是非、EUのように毎年発表して欲しいも のだ。正確なデータの公表を元に各専門家らの智恵を最大 限活用して、政府が率先して指針を示したいものだ。

我が国のエネルギー政策は大企業中心主義で進められて いる。これを改め、長期を見越して、真に国益となる方向 を各分野の専門家を交えて議論を深める必要がある ${ }^{35)}$ 。そ してバックキャストで取り組むことが必要と考える。

北欧等では、エネルギーと環境について経済優先でな く、真の国益から考え、幼稚園の時代から学んでおり、自 分が国に対して何をなしえるかを小学校の時代から学んで いる。教育の問題がある。また $\mathrm{CO}_{2}$ 排出量のハンディに比 例した炭素税を 2012 年 10 月から導入したが、まだ未熟な 部分が多く見られる。欧米のようにきめ細やかな配慮をし て、真に再生可能エネルギーの導入が進むようにしていき たい。世界はフクシマ後の日本がどのような選択をするか 見守っている ${ }^{36)}$ 。

2004 年に REN21 ネットワーク（21 世紀のための再生可 能エネルギー政策ネットワーク）が発足し、自然エネルギー の国際会議もいくつか開かれた ${ }^{34)}$ 。REN21 ネットワークは アメリカと中国がイニシャティブを取っている。日本は今 まで積極的でなかったが、今後イニシャティブを取るぐら いに参加してほしいものだ。

\section{引用文献}

1) 自然エネルギー世界白書 2011、ispe のホームページ：http:// www.isep.or.jp/

2) 朝日新聞夕刊、2012 年 6 月 6 日

3) 環境省のホームページ: http://www.env.go.jp/earth/report/h2303/cover.pdf

4) 本庄孝子、土井和之：「バイオマス資源の素顔とバイオマス利 用の実態」、環境技術、Vol.40, No.6, (2011) 322-372.

5) 省エネルギー便覧 2007 年度、省エネルギーセンター、(2007) 271.

6) 資源エネルギー庁のホームページ：http://www.enecho.meti. go.jp/saiene/index.html

7) 沖武宏 :「中国地方の小水力発電」その歴史と課題、http:// kisnet.dip.jp/ aika/hatuden/eaml.pdf\#search=' 地域 \%20 水力発電 $\% 20$ 歴史

8) 傘木宏夫：「小水力発電を生かした地域づくり」、環境技術、 Vol.39, No.3, (2010) 163-168.

9) 楠本光秀、「下水道における嫌気性污泥消化の進化」http:// suido.ipej-knk.jp/expcolumn/10_11/1010-105kusumotot.pdf\#search ='\%E4\%B8\%8B\%E6\%B0\%B4\%E9\%81\%93+\%E6\%B6\%88\%E5\%
8C\%96+\%E6\%AD\%B4\%E5\%8F\%B2

10) 桜井敏郎：用水と廃水、Vol.51, No. 4, (2009) 343-349.

11) 李玉友:「メタン発酵技術の概要とその応用展望」、JEFMA、 No.53, (2005) 4-18.

12）野池達也：用水と廃水、Vol.51, No. 4, (2009) 330-337.

13) 大型プロジェクト 20 年の歩み、通商産業調査会、(1987) 26.

14）CASA（地球環境と大気污染を考える全国市民会議）のCDROM 版 2011

15) 首相官邸のホームページ：http://www.kantei.go.jp/jp/headline/ renewable_energy.html

16）小澤徳太郎：「スウェーデンに学ぶ持続可能な社会」、朝日新 聞社、(2006) 101.

17）朝日新聞、「原発とメディア 274 子ども $15 」 2012$ 年 11 月 9 日夕刊

18)自然エネルギー世界白書 2010 http://www.isep.or.jp/images/ library/GSR2010jp.pdf

19) NEDO のホームページ、海外レポート : http://www.nedo.go.jp/ kankobutsu/report/1026/1026-02.pdf

20) 本庄孝子：「固体燃料」、高温学会誌、34(4), (2008) 146-152.

21）本庄孝子：木質（廃パレット）の炭化を通じて地域循環利用 システムの構築、環境技術、Vol.37, No.7, (2008) 505-509.

22) 平成 16 年林業白書 : http://www.rinya.maff.go.jp/seisaku/ sesakusyoukai/16hakusyo3syou.htm

23) 自然エネルギー白書 2010(日本) http://www.re-policy.jp/jrepp/ JSR2010/JSR2010_all.pdf

24) 近畿大学リエゾンセンター：KLC/NEWS 2008 年夏号、通算 11 号

25) 高槻のバイオコークス : http://bio-cokes.info/index.html

26) T. Honjo, M. Fuchihata, I. Ida, H. Sano: Prospect on new fuel BCDF (Bio-Carbonized-Densified-Fuel): the effect of Semi-Carbonization, Proceedings of the first world conference on pellets, (2002) 159-163.

27) 三井造船の HP : http://www.mes.co.jp/press/2012/20120202.html

28) 岸本定吉：“炭”、創森社、(1998) 247.

29) 藤井絢子、「菜の花エコ事典」、創森社 (2011)

30) 本庄孝子、佐野宽、㴊端学：地域における廃食油の SVO 利用、 環境技術、Vol.40, No.8, (2011) 493-498.

31) 山口裕史：日本はエネルギー大国だ、バイナミックセローズ 出版 (2011)

32) 自然エネルギー世界白書 2012、http://www.map.ren21.net/GSR/ GSR2012.pdf

33)レンヴィーバイオガス (Lemvig Biogas) : http://www. lemvigbiogas.com/JP.htm

34）飯田哲也：エネルギー政策のイノベーション、学芸出版社、 (2011) 64

35) 本庄孝子、佐野寛：バイオマスエネルギーの課題と検討、第 8 回バイオマス科学会議発表論文集、p.70-71 (2013)

36) 北澤宏一「日本は再生可能エネルギー大国になりうるか」ディ スカバリー・トゥエンティワン、(2012) 76 